\title{
Corporate Theory and Corporate Law Reform in Australia
}

\author{
Ian M. Ramsay
}

T $\mathrm{n}$ the last few years Australian corporate law has been significantly reformed. The reforms include:

- increased duties imposed upon company directors;

- regulation of transactions between public companies and their related parties;

- increased disclosure requirements for public companies;

- new liability upon parent companies where a subsidiary trades while it is insolvent and heightened liability upon directors for the insolvent trading of their companies;

- a wider definition of insider trading; and

- increased regulation of public unit trusts.

This article evaluates some of these reforms in the light of a range of current theories of the corporation.

\section{Two Theories of the Corporation}

Recent debates about corporate law focus mainly on two contrasting theories of the corporation: the managerialist (or institutionalist) theory and the contractual theory (Symposium, 1989; Macey, 1993). The theories have different implications for corporate law and therefore corporate law reform. They are both concerned with corporate governance; in particular, they both endeavour to formulate ways to ensure that the managers of companies act in the interests of shareholders. But they differ fundamentally on how this objective is to be accomplished.

The managerialist theory of the corporation emphasises corporate management and the power that it wields. The issue is whether management holds and exercises this power legitimately (Bratton, 1989:1476). Critics of management argue that man-

Ian Ramsay is Harold Ford Professor of Commercial Law at the University of Melbourne. 
agers often exercise power without accountability to shareholders; in public companies, shareholders are unable to monitor effectively the managers of their companies, so that legal intervention is needed to protect the interests of shareholders.

In the managerialist theory, accountability is secured by the imposition of mandatory legal duties upon directors and other officers. These include the duties to act honestly, to exercise care and diligence, not to make improper use of information acquired by virtue of being an officer of the company, and not to make improper use of position as an officer of the company (see s.232 of the Corporations Law ). In addition, corporate managers are subject to disclosure obligations. These obligations apply generally (for example, where a director has a personal interest in a matter that is before the board of directors - ss.231 and 232A of the Corporations Law) and in specific contexts such as where the company is raising capital from investors (Chapter 7 of the Corporations Law). These legal duties and obligations may be enforced by the company itself (where the duties are owed to the company rather than to individual shareholders), by shareholders, or by the Australian Securities Commission.

In contrast, the contractual theory of the corporation emphasises the role of market forces, rather than legal rules alone, in aligning the interests of corporate managers and shareholders. The theory is based upon the works of Coase (1937), Jensen and Meckling (1976), and Fama (1980). According to the contractual theory, competitive markets are more important than mandatory legal rules in providing managers with appropriate incentives to maximise shareholder wealth. These markets include the product market, the market for corporate control and the managerial labour market. The contractual theory does not imply the absence of legal rules, but asserts that to the extent that market forces require managers to act in the interests of shareholders, there is less need to seek this outcome through mandatory corporate rules.

Clearly, the validity of the contractual theory depends upon the efficiency of the markets. As for products markets, adherents of the theory argue that management must ensure that the company competes effectively in the market for the company's goods and services; but critics stress that product markets may not always be competitive.

The market for corporate control should similarly discipline management, since any lack of efficiency should be reflected in the company's share price, thus creating an opportunity for a raider to take over the company, install more efficient managers, and thereby realise higher profits. Yet there are limits on the effectiveness of the market for corporate control. Bebchuk (1992) asserts that the market for corporate control cannot be relied upon to discourage managers from taking action that increases their wealth at the expense of shareholders. Further, Coffee (1984) argues that the market for corporate control applies only within a limited range. Companies whose management is not inefficient enough to lower the share price to the point at which it attracts a takeover bid, and companies that are so inefficient that takeovers are deterred by the risks involved, fall outside this range. The market for corporate control may represent only a weak discipline on such companies.

1

The Corporations Law came into effect on 1 January 1991. 
The managerial labour market should operate to discipline management, since any reduction in shareholder value due to management inefficiency may reduce the employment opportunities of managers. However, there is evidence that managers typically face a very small prospect of dismissal. Summarising the results of their study of US companies, Jensen and Murphy (1990:240) claim that 'the data suggests that CEOs bear little risk of being dismissed by their boards of directors. The CEOs in our sample who leave their firms during the thirteen-year sample period hold their jobs an average of over 10 years before leaving, and most leave their position only after reaching normal retirement age'. Yet management turnover will increase in financially distressed companies (Gilson, 1989).

Since the contractual theory of the corporation relies mainly on market forces to discipline management, it envisages limiting the role of government to providing rules that deter one-off instances of management self-dealing (which cannot be prevented by market forces) and imposing standard-form contracts that reduce the transaction costs of negotiating new contracts.

\section{Additional Liabilities on Directors and Managers}

A prominent feature of recent corporate law reforms in Australia is the additional liability they impose upon directors or managers (see Redmond, 1992, for more detailed discussion). Two examples concern financial benefits to related parties of public companies and continuous disclosure obligations.

Detailed amendments to the Corporations Law designed to regulate financial benefits to related parties of public companies came into operation in February 1994. The express purpose of the amendments is to protect the resources of public companies and the interests of their shareholders by requiring that, in general, financial benefits to related parties that could diminish or endanger those resources or that could adversely affect those interests be disclosed and approved by shareholders before they are given. Any person involved in the contravention of this legislation, including directors of the public company giving the financial benefit, may suffer a penalty.

Legislative amendments to the Corporations Law relating to continuous disclosure came into effect in September 1994. Under these amendments, a range of companies and other investment vehicles that hitherto have not had to comply with the continuous-disclosure requirements of the Australian Stock Exchange will be required to immediately disclose information that is not generally available and that, if it were available, would be expected to have a material effect on the price or value of the company's securities. Any person involved in a contravention of these provisions, including any directors or managers, may be sued for damages by any person who suffers loss because of the contravention.

These two reforms are best understood in the light of the managerialist theory of the corporation. At their core lie issues of management accountability. Their objective is to enhance this accountability by increasing the legal obligations upon corporate managers. The managerialist theory also emphasises the need for enhanced monitoring of managers by shareholders. This too is recognised in the reforms, both of which 
contain increased disclosure-requirements to shareholders and, in the case of the related-party transaction reforms, require approval by shareholders of financial benefits to related parties.

Equivalent reforms in the US, in contrast, reflect the contractual theory of the corporation. Recent amendments to Delaware corporate law allow Delaware companies to amend their articles of association to eliminate monetary liability of directors to the company and its shareholders for breach of the duty of care. These amendments have been adopted by many other states (Bradley \& Schipani, 1989). The reforms emphasise voluntary contracting by shareholders and, by permitting shareholders to contract out of what was previously a mandatory duty imposed upon company directors, acknowledge that there may be other means of aligning the interests of directors and shareholders than the imposition of mandatory legal rules.

However, it should be noted that other theories have been advanced to explain the introduction of certain changes in corporate law. One of these is public choice theory, which focuses on the political process conceived as a competition among groups for political influence (Farber \& Frickey, 1991). One of the conclusions of public choice theory is that interest groups that are small, single-minded and wellorganised tend to be more influential than interest groups with diverse agendas; as a result, the political process tends to produce laws that advance the interests of wellorganised interest groups at the expense of weaker ones.

Some of the mandatory disclosure rules imposed upon companies seem consistent with public choice theory. It has been argued that the main beneficiaries of mandatory disclosure requirements in the US have been members of the professional trading community. Mandatory disclosure rules allegedly help these traders by making it cheaper to obtain, process, and verify information conceming companies. According to Gilson and Kraakman (1984:641), this explains 'the overwhelming support that the securities industry gave expansion of the disclosure system ... as well as the generally high esteem in which the industry holds most [Securities and Exchange Commission] disclosure activities'. Phillips and Zecher (1981:118) also use public choice theory to explain the expansion of the Securities and Exchange Commission's disclosure requirements:

These [disclosure requirements] are characterised by wealth transfers from investors and corporations for whom the cost is not great on a per capita basis to a relatively small group of processors [of the information], which includes securities lawyers, accountants, security analysts, and of course the Securities and Exchange Commission's employees. There is insufficient economic incentive by the members of the taxed groups to organise in opposition to this type of regulation.

\section{The Costs of the Reforms}

Whether the Australian reforms succeed in increasing managerial accountability to shareholders remains to be seen. However, some of the costs of the reforms can be 
calculated. First, there are obvious compliance costs. 'The related-party transaction reforms require shareholders to vote on a range of financial benefits from public companies to their related parties. The continuous-disclosure reforms will also impose compliance costs. These costs may have adverse effects on the productivity of Australian companies and, to the extent that foreign companies competing in the same markets as Australian companies do not have to comply with these types of rules, they will affect their competitiveness too.

A second cost, which is related to the first point, turns on the argument that the recent reforms emphasise minimum conformity by company directors with the new obligations rather than the far more important objective of company performance. This argument is summarised in a recent report

At some point over the last several years the debate about what boards of directors ought to do and be responsible for took a wrong turn. In almost every other area of economic life the debate has been about how various participants can improve the quality and volume of their productive contributions. For example, workplace reform, management development and financial deregulation are all about increasing competitiveness and productivity and achieving standards of best practice. In contrast, the debate about directors has become preoccupied with criminality, fraud, negligence and minimum standards. The worry about the rotten apple - and there have been a number - has deflected attention from the main game of wealth creation which is, in turn, the driver of new investment and job creation. . .

What we are finding is that the board's list of responsibilities is expanding, and that most of the new activities fall into the conformance rather then performance category. As these activities are added to the board's duties, its agenda becomes increasingly cluttered and pressured. Moreover, many of these new responsibilities are sheeted home to directors personally, so that there is considerable individual incentive to overkill on compliance, even if the cost is less board attention on long-term performance: (Sydney Institute, 1993:1,18)

This quotation raises for discussion the critical issue of the circumstances under which the imposition of personal liability upon directors is appropriate. It may be that, in some instances, the costs of imposing personal liability upon directors outweigh the benefits. Interestingly, economic theory has traditionally had little to say about the legal duties imposed upon directors. According to Hart (1993), this may be because neoclassical theory, which until recently dominated the economic literature on the corporation, has little or nothing to say about directors' duties because it operates with a conflict-free conception of the corporation in which selfless managers act solely in the interests of shareholders. The development of economic theories that recognise that the interests of shareholders and directors may diverge allows analysis, from an economic perspective, of directors' duties as one possible way in which the costs that arise from this divergence may be reduced (McEwin, 1992). 
From a law and economics perspective, it is appropriate to impose liability upon directors only where they can control the risks associated with liability and, where appropriate, can shift this risk to persons who are better bearers of the risk. Otherwise, directors will become risk-averse in their decision-making and fail to maximise shareholder wealth. With respect to the ability of directors to control the risks associated with their companies, it is important to note that, in the case of directors of public companies, the expectation is not that they will manage the day-to-day business of the company. Rather, the board of directors is expected to monitor management. This is recognised in the leading judgment of Justice Rogers where he stated:

The board of a large public corporation cannot manage the corporation's day to day business. That function must by business necessity be left to the corporation's executives. . . The directors rely on management to manage the corporation...

It is of the essence of the responsibilities of directors that they take reasonable steps to place themselves in a position to guide and monitor the management of the company.

The main difficulty with imposing additional personal liability upon directors is that their inability to diversify or shift this risk makes them inefficient bearers of risk. Investors of both equity and debt in companies are able to diversify their holdings and thereby minimise the risk associated with investing in any one company. However, directors are much more risk-averse because their human capital is invested in only one company. The human capital even of non-executive directors is invested in only a small number of companies and therefore cannot be fully diversified.

One way directors can diversify risk is by obtaining insurance. Recent reforms to the Corporations Law (s.241A) allow companies to pay the premiums for directors and officers' liability insurance. However, the international experience is that even where the law permits directors' and officers' insurance, it may often not be available (Daniels \& Hutton, 1993). This point should be pondered by those who believe that imposing additional liabilities upon company directors is the necessary solution to problems in the area of corporate governance.

A final cost of some of the corporate law reforms is that, because they are mandatory rules, they deny shareholders the opportunity to enter into different types of contracts with corporate mangers. This is a particular problem for legal rules introduced by a national or federal government. On the other hand, regulation introduced by a state government may be superior in facilitating shareholder choice. These issues are discussed in the next section.

\footnotetext{
2 AWA v Danjels, (1992) 7 ACSR 759 at 864 and 866.

3 A study of the largest 250 Australian companies revealed that 80 per cent of the directors of these companies held only one directorship while a further 12 per cent of the directors held only two directorships (Carroll, Stening \& Stening, 1990).
} 


\section{National or State Corporate Regulation?}

Australian corporate regulation is essentially a national system of regulation. In this respect, Australian corporate regulation differs significantly from that of some other countries where corporate law is the responsibility of state governments and the legislation can differ in substantial ways from state to state. If the goal is to facilitate shareholder choice, state governments may be better able to achieve it than the national government.

There are of course arguments that favour national regulation of companies. For example, the transaction costs associated with companies doing business can be reduced if they have to deal with uniform national law rather than a series of different state laws. In addition, regulation by the national or federal government may overcome the incentive of state governments to externalise costs. This will occur where a state government does not bear all of the costs of action that it undertakes.

Yet there are powerful arguments favouring state government regulation of companies (McEwin, 1990; Ramsay, 1990). The federal government may be more insensitive than state governments to the needs of shareholders and other participants in companies. Indeed, it is a fundamental rationale of federalism that governments with different jurisdictions can better satisfy the enormous variety of preferences in society (including the preferences of shareholders).

Another argument favouring state regulation is that a state government has less scope for enacting harmful legislation than the federal government. This is because the more local the jurisdiction of a government is, the more readily people and businesses can move in order to find a more hospitable jurisdiction: in other words, each government serves as a substitute for the others. Again, national regulation of companies makes it difficult to determine whether this regulation is optimal because there is no competition for the provision of corporate regulation. Companies and their shareholders do not have a choice and cannot indicate their preference for alternative regulation by incorporating in another jurisdiction. Finally, allowing regulation by state governments can increase innovation and experimentation as each government competes to attract business and employment by enacting corporate legislation that is attractive to companies and their shareholders.

Federal regulation can indeed stifle commercial innovations. In recent years limited partnerships have emerged as an alternative form of financing investment in particular projects. Partnerships are subject to state government regulation (each state has its own Partnership Act). However, the federal government intervened in the 1992/93 federal budget to provide that limited partnerships would be taxed in the same way as companies. Prior to this, limited partnerships enjoyed a significant tax advantage over other business structures such as companies in that they allowed the flow-through of partnership losses to individual partners that could be offset against a partner's other assessable income. The effect of this announcement by the federal government was a substantial decline in the registration of new limited partnerships (Ramsay, 1993).

Another example concerns partial takeovers. A partial takeover occurs where an attempt is made to gain control of a company by purchasing less than 100 per cent of the voting shares of that company. Partial takeovers used to constitute an important 
part of the market for corporate control in Australia, at one time accounting for well over 20 per cent of all takeovers undertaken. However, in 1986, the federal government introduced amendments that effectively saw the demise of partial takeovers. The year after the amendment, partial takeovers constituted only 6 per cent of all takeovers and have never constituted more than 5 per cent since (Ramsay, 1992).

\section{Conclusion}

The pace of corporate law reform in Australia has quickened considerably. Much of the reform is best understood in the light of the managerialist theory of the corporation, which emphasises the importance of legal duties and obligations imposed on corporate managers.

Insufficient attention has been paid, however, to the costs of the some of the reforms. These include compliance costs and an emphasis on company directors' compliance with the new laws at the expense of their performance. Additional costs arise because the reforms are mandatory, thus denying shareholders the opportunity to enter into alternative contractual arrangements with company managers. Corporate governance would perhaps be more effectively reformed by changes that facilitate shareholder choice.

\section{References}

Bebchuk, L. (1992), 'Federalism and the Corporation: The Desirable Limits on State Competition in Corporate Law', Harvard Law Review 105: 1437-510.

Bradley, M. \& C. Schipani (1989), "The Relevance of the Duty of Care Standard in Corporate Governance', Iowa Law Review 75: 1-73.

Bratton, W. (1989), 'The New Economic Theory of the Firm: Critical Perspectives From History', Stanfond Law Review 41: 1471-527.

Carroll, R., B. Stening \& K. Stening (1990), 'Interlocking Directorships and the Law in Australia', Company and Securities Law Journa/8: 290-302.

Coase, R. (1937), 'The Nature of the Firm', Economica 4: 387-405.

Coflee, J. (1984), 'Regulating the Market for Corporate Control: A Critical Assessment of the Tender Offer's Role in Corporate Governance', Columbja Law Review 84: 1145-296.

Daniels, R. \& S. Hutton (1993), 'The Capricious Cushion: The Implications of the Directors' and Officers' Insurance Liability Crisis on Canadian Corporate Governance', Canadian Business Law Journal 22: $182-230$.

Fama, E (1980), 'Agency Problems and the Theory of the Firm', Journal of Political Economy 88: 228306.

Farber, D. \& P. Frickey (1991), Law and Public Choice: A Critical Introduction, University of Chicago Press, Chicago. 
Gilson, R. \& R. Kraakman (1984), 'The Mechanisms of Market Efficiency', Vinginia Law Review 70: 549. 644.

Gilson, S. (1989), 'Management Turnover and Financial Distress', Joumal of Financial Economics 25: $241-62$.

Hart, O. (1993), 'An Economist's View of Fiduciary Duty', University of Toronto Law Joumal 43: 299313.

Jensen, M. \& W. Meckling, (1976), 'Theory of the Firm: Managerial Behavior, Agency Costs, and Ownership Structure', Joumal of Financial Economics 3: 305-60.

— (1990), 'Performance Pay and Top-Management Incentives', Joumal of Political Economy 98: 22564.

Macey, J. (1993), 'Corporate Law and Corporate Governance', Journal of Corporation Law 18: 185-211.

McEwin, I. (1990), 'Federal vs State Incorporation: Why the High Court got it Right', Policy6(2): 50-3.

— (1992), 'Public Versus Shareholder Control of Directors', Company and Securities Law Journal 10: 182-204.

Phillips, S. \& R. Zecher (1981), The SEC and the Public Interest, MTT Press, Cambridgc, Mass.

Ramsay, I. (1990), 'Company I aw and the Economics of Federalism', Federal Law Review 19: 169-202.

- (1992), 'Balancing Law and Economics: The Case of Partial Takeovers', Joumal of Business Law $369-97$.

— (1993), 'The Expansion of Limited Liability: A Comment on Limited Partnerships', Sydney Law Review 15: 537-46.

Redmond, P.(1992), 'The Reform of Directors' Duties', University of New South Wales Law Joumal 15: 86-126.

Sydney Institute (1993), Strictly Boardroom: Improving Governance to Enhance Company Performance, The Business Library, Sydney.

Symposium (1989), 'Contractual Freedom in Corporate Law', Columbja Law Review 89: 1395-757.

I am grateful for the helpful comments of two anonymous referees. 